Editorial

\title{
Wetlands and Sustainability
}

\section{Richard Smardon}

Department of Environmental Studies, SUNY College of Environmental Science and Forestry, 1 Forestry Drive, Syracuse, NY 13210, USA: E-Mail: rsmardon@esf.edu; Tel.: +1-315-470-6576; Fax: +1-315-470-6915

External Editor: Miklas Scholz

Received: 17 November 2014; in revised form: 24 November 2014 / Accepted: 26 November 2014 / Published: 28 November 2014

\begin{abstract}
This editorial provides an overview of the special issue "Wetlands and Sustainability". In particular, the special issue contains a review of Paul Keddy's book "Wetland Ecology" with specific reference to wetland sustainability. It also includes papers addressing wetland data acquisition via radar and remote sensing to better understand wetland system dynamics, hydrologic processes linked to wetland stress and restoration, coastal wetlands land use conflict/management, and wetland utilization for water quality treatment.
\end{abstract}

Keywords: wetland stress and ecology; sustainability; data acquisition; hydrology; land use conflict; water quality treatment

Wetlands are among the worlds most stressed ecosystems [1-3] but these same systems also provide ecosystem services [4,5] for both developing and developed societies. The issue facing us is how can we better understand wetland ecological systems and the stresses on such systems from both anthropocentric and natural causes, as well as cumulative effects such as climate change.

To understand how wetlands behave over time we need better data and so Gallant et al. [6] address monitoring wetland vegetation emergence, growth and senescence. Gallant et al. [6] utilize polarimetric synthetic aperture radar to track seasonal changes and to distinguish wetland features from surrounding upland features. Research has also been done at State University of New York's College of Environmental Science and Forestry on utilization of multi-spectral imagery to distinguish wooded wetland from surrounding upland forest and so the use of such imagery is critical to understanding wetland change over time. 
Books by Keddy [1] and Mitch and Gosselink [2] are utilized for wetland ecology textbooks. The book review by Smardon [7] focuses on Keddy's treatment of basic wetland processes such as flooding, fertility, disturbance, competition, herbivary, burial, diversity and zonation, all in relation to wetland sustainability science. Papers by Berthelot et al. [8] and Zedler et al. [9] address the influence of water level fluctuations and upstream water quality on wetland vegetative community health and diversity. Berthelot et al. [8] look specifically at spring flooding on riparian tree forests, while Zedler et al. [9] address upstream water quality impacts on the Leopold Arboretum wetlands management and restoration. Both hydrologic processes are major drivers of wetland vegetation community sustainability.

Sabastia-Frasquet et al. [10] address the issue of land-use control and coastal wetland sustainability in the Spanish Western Mediterranean coast. The authors address the issue of local versus regional policy consistency as it affects coastal wetland management especially for agricultural use versus wetland preservation or restoration. This a worldwide issue of concern for coastal wetland management [3].

Finally two papers that address the use of natural [11] versus constructed wetlands [12] for water quality treatment. The use of natural, modified, and constructed wetlands is a rapidly growing arena of wetland utilization [13] but not without controversy. Some scientists and regulatory agencies object to the use of "natural" wetlands for such use. The paper by Chouinard et al. [11] assesses the role of natural tundra wetlands for treatment of municipal wastewater in the Canadian Artic by using a wetland simulation model to predict management option outcomes and treatment capacity. Tao et al. [12] review the new use of constructed wetlands to treat combined sewer overflows in European and North American urban areas as opposed to mechanical "grey infrastructure" treatment plants.

All these papers and the book review are important to progress the understanding of wetlands and sustainability. Such work becomes even more imperative as regional climate change will alter both anthropocentric and natural stresses, hydrologic regimes, land use conflict. Such research is also needed to provide scientific methods for better assessment of wetland ecosystem services.

\section{References}

1. Keddy, P.A. Wetland Ecology Principles and Conservation: Cambridge University Press: Cambridge, UK, 2010.

2. Mitsch, W.J.; Gosselink, J.G. Wetlands, 3rd ed.; John Wiley and sons: New York, NY, USA, 2000.

3. Smardon, R.C. Sustaining the Worlds wetlands; Setting Policies and Resolving Conflicts; Springer Press: New York, NY, USA, 2009.

4. Millennium Ecosystem Assessment (MEA). Ecosystems and Human Well Being, Wetlands and Water Synthesis; Water Resources Institute: Washington, DC, USA, 2005.

5. Emerton, L. Values and Rewards: Counting and Capturing Ecosystem Water Services for Sustainable Development; IUCN Water, Nature and Economics Technical paper No. 1; International Union for Conservation of Nature (IUCN): Cambridge, UK, 2005.

6. Gallant, A.L.; Kaya, S.J.; White, L.; Brisco, B.; Roth, M.F.; Sadinski, W.; Rover, J. Detecting emergence, growth and senescence of wetland vegetation with polarimetric synthetic aperture radar (SAR) data. Water 2014, 6, 694-722. 
7. Smardon, R.C. Wetland Ecology Principles and Conservation, Second Edition. Water 2014, 6, 813-817.

8. Berthelot, J.-S.; Saint-Laurent, D.; Gervais-Beaulac, V.; Savoie, D. Assessing the effects of periodic flooding on the population structure and recruitment rates of riparian tree forests. Water 2014, 6, 2614-2633.

9. Zedler, J.B.; Doherty, J.M.; Rojas, I.M. Leopold's Arboretum needs upstream water treatment to restore wetlands downstream. Water 2014, 6, 104-121.

10. Sebastia-Frasquet, M.-T.; Altur, V.; Sanchis, J.-A. Wetland planning: Current problems and environmental management proposals at supra-municipal scale (Spanish Mediterranean Coast). Water 2014, 6, 620-641.

11. Chouinard, A.; Yates, C.N.; Balch, G.C.; Jorgensen, S.E.; Wooton, B.C.; Anderson B.C. Management of tundra wastewater treatment wetlands within a lagoon/wetland hybridized treatment system using the Subwet 2.0 wetland model. Water 2014, 6, 439-454.

12. Tao, W.; Bays, J.S.; Meyer, D.; Smardon, R.C.; Levy, Z.F. Constructed wetlands for treatment of combined sewer overflow in the US: A review of design challenges and application status. Water 2014, 6, 3362-3385.

13. Kadlec, R.H.; Wallace, S.D. Treatment Wetlands, 2nd ed.; CRC Press: Boca Raton, FL, USA, 2009.

(C) 2014 by the authors; licensee MDPI, Basel, Switzerland. This article is an open access article distributed under the terms and conditions of the Creative Commons Attribution license (http://creativecommons.org/licenses/by/4.0/). 